\title{
An Application of Non-Parametric Method and Simple Linear Regression in Rainfall Partitioning in Tropical Lowland Forest of Sepilok Forest Reserve, Sabah
}

\author{
Maznah Mahali1 ${ }^{*}$, Shazrul Azwan Johari ${ }^{1}$, Siti Rahayu Mohd Hashim¹, Reuben Nilus², \\ Hafizan Juahir ${ }^{3}$, Colin R. Maycock ${ }^{1}$, Mazlan Hashim4, Mui How-Phua ${ }^{1}$, Kawi Bidin ${ }^{1}$ \\ ${ }^{1}$ Faculty of Science and Natural Resources, Universiti Malaysia Sabah, Sabah, Malaysia \\ ${ }^{2}$ Forest Research Center, Sabah Forestry Department, Sabah, Malaysia \\ ${ }^{3}$ East Coast Environmental Institute, Universiti Sultan Zainal Abidin, Terengganu, Malaysia \\ ${ }^{4}$ Geoscience and Digital Earth Centre, Universiti Teknologi Malaysia, Johor, Malaysia
}

\begin{abstract}
This study was conducted in the alluvial forest and heath forest in the lowland tropical forest of Sepilok Forest Reserve, Sabah, Malaysia. The main objective was to assess how forest structure regulates rainfall partitioning in both forests. Field monitoring involved a series of forest inventory work to determine the forest stand characteristics. Mann Whitney U test was performed to compare physical characteristics between the two forests. Meanwhile rainfall partitioning was quantified by measuring the throughfall (Tf) for a period of 12 months in ten (15 x $15 \mathrm{~m}$ ) Tf plots and a simple linear regression was conducted to obtain a regression model to estimate Tf. In terms of stand structure characteristics, data in the alluvial forest indicates wider variation. Percentage of Tf as of gross rainfall $(\mathrm{Pg})$ is higher in the heath forest than in alluvial forest with the value of $89.5 \%$ and $76.8 \%$, respectively. Representative trees were selected for stemflow (Sf) estimation at each forest type. The estimated Sf is $0.2 \%$ in alluvial forest and $0.5 \%$ in heath forest. In this study, tree diameter at breast height (Dbh) and height as well as aboveground biomass were identified to have some influence in Tf and Sf production.
\end{abstract}

Keywords: rainfall partitioning; gross rainfall; throughfall; stemflow; Mann Whitney U; simple linear regression

\section{INTRODUCTION}

Rainfall partitioning by forest canopy is part of the hydrological cycle under forest environment. It has the implications in the prediction of canopy interception loss, water balance, estimation of water yields or water available for plants uptake and storage (Thimonier, 1998; McJannet et. al., 2007; Jiménez-Rodríguez, 2014; Kato et. al., 2013).The rainwater that is able to pass through the forest canopy by dripping through leaves and branches or directly through forest gaps, is known as Tf, whereas $\mathrm{Sf}$ is the intercepted water that flow down the trunk or stem of the tree (Crockford \& Richardson, 2000; Chappell et al., 2001; Aisah et al., 2012;Macinnis-Ng, 2012). During the process of rainfall interception, some of the retained water is lost back to the atmosphere through evaporation, which is referred to as the wet canopy evaporation (Chappell et. al., 2001; Aisah et. al., 2012; Park \& Cameron, 2008). By calculating the difference between gross precipitation measured above canopy or in the adjacent open area and net rainfall i.e., is the sum of Tfand Sf, the amount of water intercepted by or evaporated from forest's canopy can be estimated (McJannet 
et. al., 2007; Levia et. al., 2010).

Although there are many related studies of rainfall partitioning, each study is limited to the local environment. Liu et. al., (2013) emphasizes that the results of such study is site specific since it is heavily influenced not only by the type of vegetation of an area, but also by geographical factors, rainfall and climatic characteristics of the site. Similar studies are also considerably limited in the wet tropical rainforest which is characterized by high temperature \& high humidity (Loescher, 2002; Holwerda, 2006; Zimmermann, 2008). This study is conducted in the alluvial forest and heath forest in the Sepilok Forest Reserve (SFR), Sandakan, Sabah, the Borneo part of Malaysia. The main aim of this study was to assess how forest structure regulates rainfall partitioning in both forests. Whilst, the specific objectives of the study were to (1) determine the forest stand structure, (2) assess the rainfall partitioning and, (3) identify if any of the stand structure variable may influence the rainfall partitioning in the study site

The findings of the study will provide better understanding of the ecohydrology relationship involved that would be essential for future conservation planning and management, especially with regards to climate change issue.

\section{MATERIALSANDMETHOD}

\section{A. Study Site Information}

The study site is located in SFR ( $\left.5^{\circ} 10^{\prime} \mathrm{N}, 117^{\circ} 56^{\prime} \mathrm{E}\right)$ at the east coast district of Sabah, namely Sandakan as shown in Figure 1. Known as lowland mixed dipterocarp forest, several parts of the area was logged within the years 1930 s to 1960s (Hutton, 2013). Currently, the forest reserve is managed by the Sabah Forestry Department for protection and research. According to Nilus (2004), the vegetation in SFR is influenced by the soil series found in the area. Of the total area, 3 types of forest can be found here; the alluvial forest (61.36\%), heath forest (22.00\%) or also known as kerangas and sandstone hill forest (16.63\%). The total area of SFR is4, 294 ha and this study will only focus on the 2 major forest type which are the alluvial forest and heath forest.

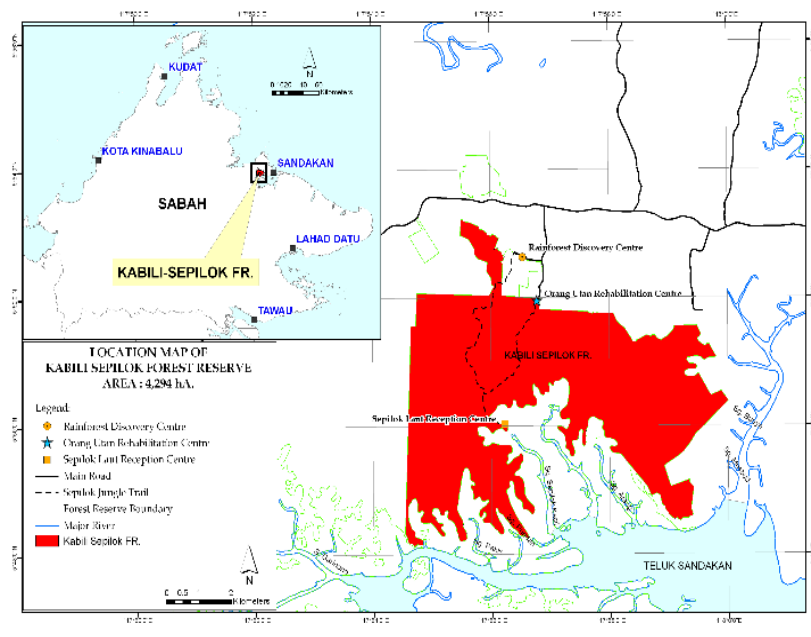

Figure 1. Location of study area

Source: Remote Sensing \& GIS Unit, Sabah Forestry

Department (2016)

\section{B. Forest Structure}

In assessing the general forest characteristics, 6 plots $(30 \mathrm{~m}$ x $30 \mathrm{~m}$ ) were established for each forest type. Series of inventory work was done in the field to gather basic information on the forest structure. From these 6 plots, 10 smaller plots ( $15 \mathrm{~m}$ x $15 \mathrm{~m}$ ) were established and named as the Tf plots in both forest type. For these plots the Dbh, tree height (total height), Lorey's height and crown projection area were determined for trees with $\mathrm{Dbh} 10 \mathrm{~cm}$ and above. Lorey's mean height weights the contribution of trees to the stand height by their basal area (Woodget, 2007). Whereas, the above ground biomass (AGB) was estimated using algometric equation mentioned by Chave et al. (2014) and calculated in Mui-How et al. (2017).

\section{Gross Rainfall (Pg), Throughfall (Tf) and Stemflow (Sf)}

Pg and Tf was collected with trough-type collectors similar to Germer et. al., (2006) and Molina\& del Campo (2012). PVC pipes with $10.2 \mathrm{~cm}$ diameter and $205 \mathrm{~cm}$ long were used to build the troughs, whereby each trough was connected to a 21 litres plastic container via rubber hose. 60 troughs per forest type were placed on the ground supported by approximately $1 \mathrm{~m}$ height iron stands and located systematic-random in the $10 \mathrm{Tf}$ plots. Similar trough-type collector was located at the nearby open area for $\mathrm{Pg}$ collection. Both Pg and Tf was measured manually at intervals of 5 to 10 days within 27 May 2014 to 27 May 2015. 
The collected rainfall was measured manually using a graduated cylinder and convert to $\mathrm{mm}$ depth by dividing the rainfall volume collected with the receiving area of the trough (Germer et. al., 2006; Molina \& del Campo, 2012; Yusop, 2003).

For Sf estimation, all trees with $\mathrm{Dbh} \geq 10.0 \mathrm{~cm}$ were selected in the $15 \times 15 \mathrm{~m}$ alluvial and heath forest plot. A collar type gauge was fitted to each of the identified sample tree at approximately $1.3 \mathrm{~m}$ height above the forest floor, in order to collect the rainwater that was diverted to the tree stem and finally to a plastic container. Frequency of Sf measurement were similar to $\mathrm{Tf}$ data collection within the period of October 2014 to May 2015.

\section{Data Analyses}

Descriptive analyses and simple linear regression were conducted to identify which of the forest structure characteristic have control on the rainfall partitioning in the study site. Data distribution illustrated using scatter plot and bar chart where suitable.

\section{RESULTS AND DISCUSSIONS}

\section{A. Forest Stand Characteristics}

The result of the forest inventory is shown in Table 1 . The heath has more trees than the alluvial forest. And through observation, trees in the heath forest are mostly slender with the maximum tree Dbh can be found here is $81.0 \mathrm{~cm}$. In relation to this, the total basal area for heath forest (30.78 $\left.\mathrm{m}^{2} / \mathrm{ha}\right)$ is lesser that alluvial forest $\left(37.12 \mathrm{~m}^{2} / \mathrm{ha}\right)$. Soils in alluvial forest had higher concentrations of nitrate, total $\mathrm{N}$, $\mathrm{P}$ and exchangeable $\mathrm{Mg}$ and $\mathrm{K}$ which indicates that the particular forest is able to support greater growth of trees (Nilus, 2004). Whilst trees in heath forest usually are stressful due to nutrient deficiency in the soil, therefore the trees generally grown into short stature and slender trees (Whitmore, 1975). Mann Whitney U test was performed as an alternative method for independent t-test since the normality assumption is not fulfilled. The test indicates that alluvial forest and heath forest have significant different in terms of Dbh distribution, tree height, basal area and number of trees $(\mathrm{p}<0.05)$.
Table 1. Forest Physical Characteristics

\begin{tabular}{|c|c|c|}
\hline $\begin{array}{c}\text { Forest } \\
\text { Characteristic }\end{array}$ & Alluvial & Heath \\
\hline Nu. of Trees (n) & 254 & 346 \\
\hline \multicolumn{3}{|l|}{ Dbh (cm); } \\
\hline Mean & $23.0 \pm 21.8$ & $21.5 \pm 12.3$ \\
\hline Range & $10.00-145.0$ & $10.00-81.0$ \\
\hline \multicolumn{3}{|l|}{ Tree Height (m); } \\
\hline Mean & $18.4 \pm 10.4$ & $19.8 \pm 6.4$ \\
\hline Range & $4.5-68.5$ & $5.0-55 \cdot 4$ \\
\hline Tree Density (/ha) & 470 & 641 \\
\hline $\begin{array}{c}\text { Total Basal Area } \\
\left(\mathrm{m}^{2} / \mathrm{ha}\right)\end{array}$ & 37.117 & 30.777 \\
\hline
\end{tabular}

Trees in the representative plots were identified up to species and family level. The dominant family in alluvial forest is Dipterocarpaceae, meanwhile Myrtaceae is the dominant family in heath forest as shown in Figure 2 and Figure 3. Dipterocarpaceae tree species can grow very large and tall, therefore the largest tree found in the alluvial forest was Shorealeprosula $(\mathrm{Dbh}=145.0 \mathrm{~cm})$.

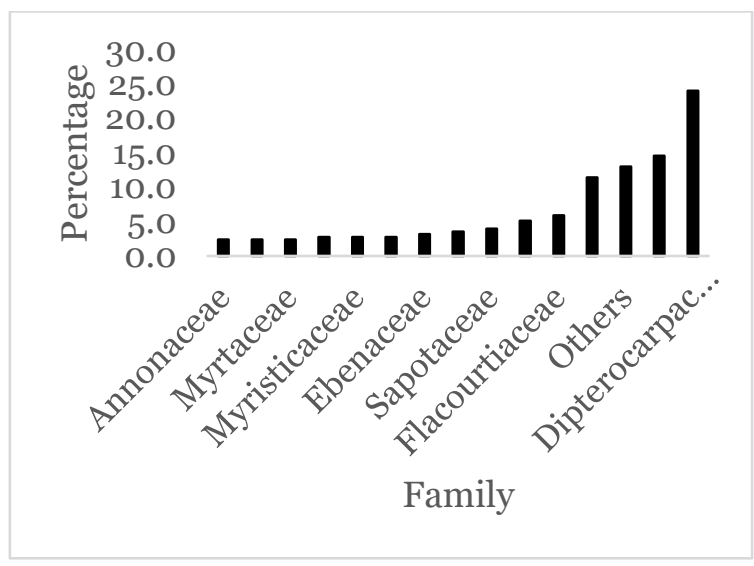

Figure 2. Family of Trees in Alluvial Forest 


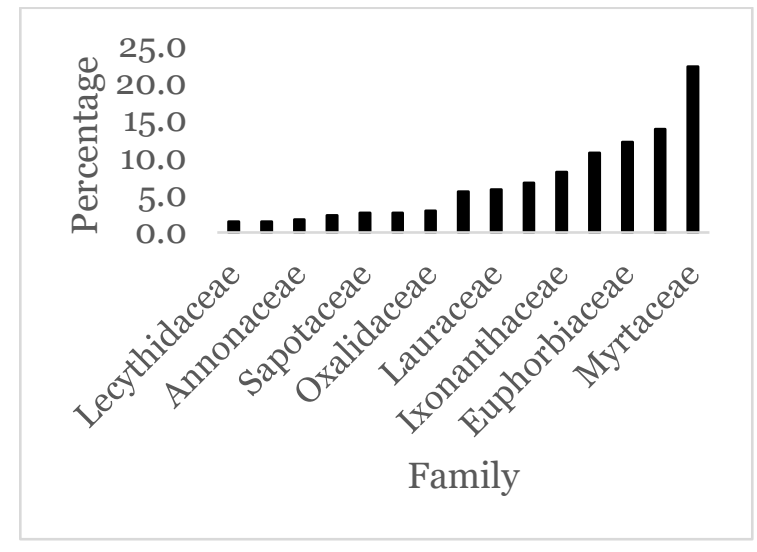

Figure 3. Family of Trees in Heath Forest

Table 2 shows the forest stand characteristics at Tf plots level. Each forest type is represented by 10 plots. The number of trees in each plot is used to calculate the tree density at plot level and level up to per Ha area. The tree basal area is estimated using the equation of $\pi r^{2}$ (i.e. area of a circle, $\mathrm{m}^{2}$ ) where $\mathrm{r}$ is equals to tree Dbh divide by 2 .

Table 2: Stand Structure in Throughfall (Tf)

Plots

\begin{tabular}{|c|c|c|}
\hline $\begin{array}{c}\text { Stand Structure } \\
\text { Variables }\end{array}$ & $\begin{array}{c}\text { Alluvial } \\
\text { Forest } \\
\text { n=10 plots }\end{array}$ & $\begin{array}{c}\text { Heath } \\
\text { Forest } \\
\text { n=10 plots }\end{array}$ \\
\hline $\begin{array}{c}\text { Mean Tree Density } \\
\text { per Ha } \pm \text { Std. Dev. } \\
\text { Range }\end{array}$ & $485 \pm 156$ & $564 \pm 171$ \\
\hline $\begin{array}{c}\text { Mean Dbh (cm) } \pm \\
\text { Std. Dev. } \\
\text { Range }\end{array}$ & $23.5 \pm 7.2$ & $22.6 \pm 4.2$ \\
\hline $\begin{array}{c}\text { Mean Height (m) } \\
\pm \text { Std. Dev. } \\
\text { Range }\end{array}$ & $20.7 \pm 6.6$ & $19.4 \pm 2.0$ \\
\hline $\begin{array}{c}\text { Mean Lorey's Height } \\
\text { Std. Dev. } \\
\text { Range }\end{array}$ & $30.7 \pm 16.7$ & $23.1 \pm 4.1$ \\
\hline $\begin{array}{c}\text { Mean Total Basal } \\
\text { Area (m²) } \pm \text { Std. Dev. } \\
\text { Range }\end{array}$ & $0.90 \pm 0.86$ & $0.71 \pm 0.36$ \\
\hline $\begin{array}{c}\text { Mean AGB (ton/Ha) } \\
\text { Std. Dev. } \\
\text { Range }\end{array}$ & $705.3 \pm 855.2$ & $349.2 \pm 224.6$ \\
\hline & 2214.9 & 695.2 \\
\hline
\end{tabular}

It is safe to conclude that trees in alluvial plots indicated higher variation of forest characteristics than heath forest by showing a wider range of data distribution in most of the variables except for mean tree density per Ha. The values of standard deviation for the related variables also illustrate similar observation. The lowland rainforest in tropical regions are known to have a complex structure due to its high species diversity.

\section{B. Rainfall and Throughfall (Tf)}

The total rainfall measured in both forest types was 1138.8

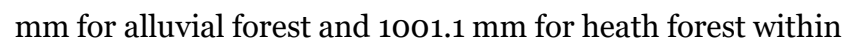
the study period. The plots for each forest type are located approximately $2 \mathrm{~km}$ apart, therefore spatial variation in terms of $\mathrm{Pg}$ was observed. The result forPg and $\mathrm{Tf}$ distribution is shown in Table 3. Lower percentage of Tf resulted in alluvial forest demonstrates that more rain was intercepted by the forest canopy. It also demonstrates that vegetation in alluvial forest have higher capacity in intercepting the rainwater that falls through the forest canopy. Although the estimated Tf percentage in this study is considered low as compared to other study within lowland tropical rainforest region, it is still consistent with findings from previous study. In Central Kalimantan, Indonesia, Vernimmen et al. (2007) quantified Tf percentage $82.8 \%$ as of Pg in the lowland evergreen rainforest site, $89.1 \%$ in tall heath forest and $76.7 \%$ in stunted heath forest. In another study, the total of $\mathrm{Tf}$ and Sf combined resulting $11 \%$ in interception rate (Asdak et al., 1998). Whilst, Chappell et al., (2001) estimated the lowland dipterocarp forest, at Eastern Sabah, Malaysia allowed $91 \%$ of the Pg to reach the ground as Tf.

Table 3. The Gross Rainfall (Pg) and

Throughfall (Tf) Characteristics

\begin{tabular}{ccc}
\hline Variable & $\begin{array}{c}\text { Alluvial } \\
\text { Forest }\end{array}$ & Heath Forest \\
\hline Gross Rainfall, Pg (mm) & & \\
Mean (std. dev.) & $40.7 \pm 27.8$ & $34.5 \pm 25.1$ \\
Range & $7.9-101.1$ & $5.6-105.6$ \\
Total & 1138.8 & 1001.1 \\
& & \\
Throughfall, Tf (mm) & & \\
Mean (std. dev.) & $31.2 \pm 21.0$ & $30.9 \pm 25.1$ \\
Range & $0.5-103.2$ & $0.1-105.9$ \\
Total & 875.0 & 896.3 \\
\hline
\end{tabular}




\begin{tabular}{ccc}
\hline & & \\
Tf/Pg (\%) & & \\
Total & 76.8 & 89.5 \\
Range & $12.1-110.8$ & $14.1-127.4$ \\
\hline
\end{tabular}

Tf shows the same trend of relationship with Pg for both forests. High correlation between Pg and Tf can be observed. This relationship is being illustrated in the scatterplots shown in Figure 4 and 5.

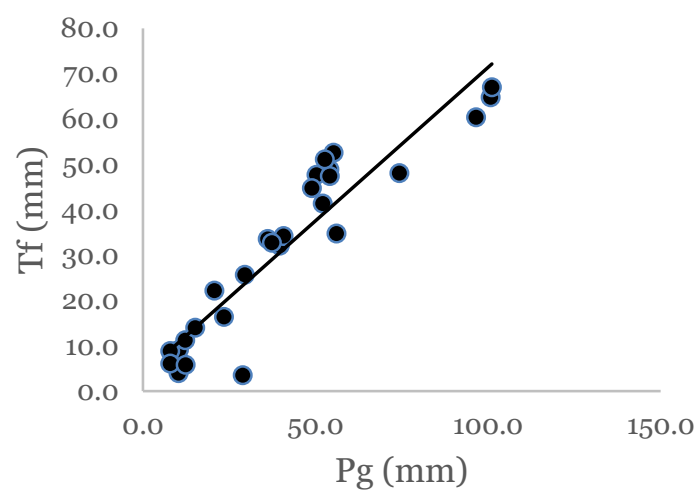

Figure 4. Relationship between Gross Rainfall

(Pg)and Throughfall (Tf) in Alluvial Forest

The relationships can be expressed by the following equation:

Alluvial Forest,

$\mathrm{Tf}=0.677 \mathrm{Pg}+3.725 \quad\left(\mathrm{R}^{2}=0.87\right)$

Heath Forest,

$\mathrm{Tf}=0.943 \mathrm{Pg}-1.642\left(\mathrm{R}^{2}=0.94\right)$

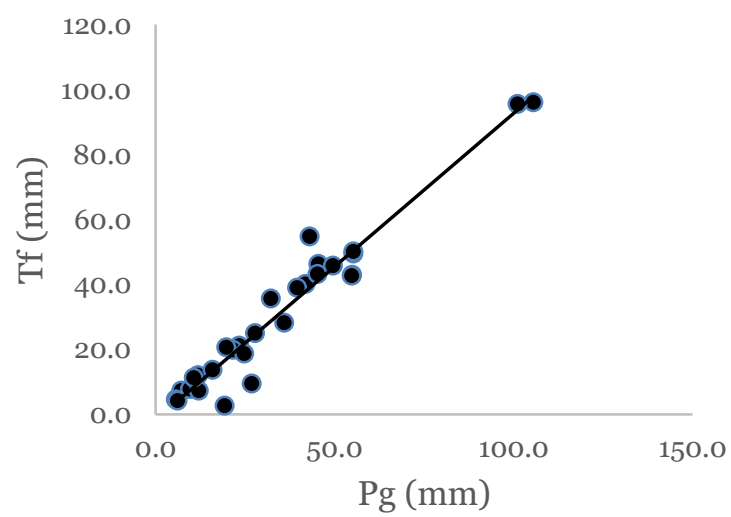

Figure 5. Relationship between Gross Rainfall (Pg) and Throughfal (Tf) in Heath Forest
However, in order to get the best estimation model for $\mathrm{Tf}$ with the presence set of data, we did model validation. Linear regression model with the least root mean squared error (RMSE) will be considered as the best fit model. As a result, the best model is shown inTable 4. The result of the study clearly shows that amount of Pg highly influenced the rate of Tf. However, the rate may vary due to the different characteristics of rainfall besides volume, such as rainfall intensity and duration of rain event. Based on the linear relationship established, high $\mathrm{R}^{2}$ value was obtained for both alluvial and heath forests $\left(\mathrm{R}^{2} \geq 0.9\right)$, indicating the strength of the linear relationship between the amount of incident rainfall received and Tf. Several studies have also resulted in a similar strong relationship, with $\mathrm{R}^{2}$ value greater than or equal to 0.9 in other forest types (McJannet et. al., 2007; Aisah et. al., 2012; Staelens et. al., 2008). Despite the difference in study sites and forest type, the similar strong relationship between $\mathrm{Pg}$ and $\mathrm{Tf}$ can be observed in most studies related to rainfall interception under forest ecosystem

Table 4. Best Fit Model for Gross Rainfall (Pg) versus Throughfall (Tf)

\begin{tabular}{|c|c|c|c|}
\hline $\begin{array}{c}\text { Forest } \\
\text { Type }\end{array}$ & $\begin{array}{c}\text { Number of } \\
\text { Data Used in } \\
\text { Calculation }\end{array}$ & $\begin{array}{c}\text { RMSE } \\
\%\end{array}$ & Model \\
\hline Alluvial & $\begin{array}{l}\text { Model }=20 \\
\text { Validate }=8\end{array}$ & 30.2 & $\begin{array}{c}\mathrm{Tf}=0.69 \mathrm{Pg}+ \\
3.29 \\
\mathrm{R}^{2}=0.92\end{array}$ \\
\hline Heath & $\begin{array}{c}\text { Model }=20 \\
\text { Validate }=8\end{array}$ & 22.6 & $\begin{array}{c}\mathrm{Tf}=0.87 \mathrm{Pg}+ \\
0.71 \\
\mathrm{R}^{2}=0.97\end{array}$ \\
\hline
\end{tabular}

\section{Forest Structure and Throughfall (Tf)}

Selected forest stand structure variables were selected to assess their contribution to the rainfall partitioning process. Linear regression analyses were conducted in order to be comparable to the result obtained by Dietz et. al., (2006). Results are shown in Table 5. Among the 4 variables, Dbh and AGB indicates higher influence on the Tf amount relative to $\mathrm{Pg}$. 
Table 5: Coefficient of Determination $\left(\mathrm{R}^{2}\right)$ and Correlation Coefficient Value Based on Linear Relationship Between Forest Stand Structure Variables and Gross RainfallThroughfall (Pg-Tf) Coefficient

\begin{tabular}{|l|c|}
\hline Stand Structure Variables & $\mathbf{R}^{2}(\mathbf{r})$ \\
\hline Dbh & $0.418(-0.6)$ \\
\hline Height & $0.039(-0.2)$ \\
\hline Density & $0.161(-0.4)$ \\
Basal Area & $0.061(-0.3)$ \\
\hline Total AGB & $0.300(-0.5)$ \\
\hline
\end{tabular}

Land cover type and vegetation characteristic plays an important role in Tf fluxes. Study by Dietz et al. (2006) found that the highest $\mathrm{Tf}$ percentage was measured in the agroforestry plots (81\%) with mid basal area of $23.7 \mathrm{~m}^{2} / \mathrm{Ha}$ whilst the lowest was in the natural forest plots (70\%) with mid basal area of $51.1 \mathrm{~m}^{2} /$ ha. Some examples of correlation coefficient value (r) obtained in the study (Tf percentage versus forest structure variables) are Dbh (-0.69), tree height (-0.74) and crown extension (-0.61) for trees with stem $\mathrm{Dbh}$ of $\geq 10 \mathrm{~cm}$. In addition, no significant correlation can be found for tree density and basal area. The study was conducted in 4 different forest management units which are; natural forest, forest with small timber extraction, forest with large timber extraction and agroforestry site (i.e. cacao under trees remaining from the natural forest) in Central Sulawesi. It is understood that the study sites in Dietz et. al., (2006) were highly different from each other in terms of the stand structure that may have great influence in the outcome of the related analyses and results.

\section{Stemflow}

The characteristics of the selected trees with $\mathrm{Dbh} 10 \mathrm{~cm}$ and above for Sf estimation are presented in Table 6. A total of 8 and 11 trees were identified for Sf collection in the alluvial and heath forest, respectively. In order to estimate $\mathrm{Sf}$ in $\mathrm{mm}$ depth, the total volume of Sf was divided by the plot area. The Sf fractions relative to $\mathrm{Pg}$ were quantified as $0.2 \%$ and $0.5 \%$ of the incident rainfall in alluvial and heath forest, respectively. The trees that generated high volume of Sf were among the tallest trees within the plot, therefore forming part of the main canopy in the forest. The tree's crown had the advantage of 'capturing' the rainfall directly and generates Sf. Asdak et. al., (1998) stated that trees in or below main canopy often had greater Sf. As cited by Hofhansl et al., (2012), taller trees that were able to reach higher canopy strata were the one to produce Sf faster.

Table 6: Summary of Tree Characteristics for Stemflow (Sf) Estimation

\begin{tabular}{|c|c|c|}
\hline Study Plots & Alluvial Forest & $\begin{array}{l}\text { Heath } \\
\text { Forest }\end{array}$ \\
\hline Nu. of Trees (n) & 8 & 11 \\
\hline $\begin{array}{c}\text { Dbh (cm) } \\
\text { Range }\end{array}$ & $10.1-40.5$ & $10.0-67.8$ \\
\hline $\begin{array}{l}\text { Height }(\mathrm{m}) \\
\text { Range }\end{array}$ & $12.2-23.1$ & $7.8-26.6$ \\
\hline $\begin{array}{l}\text { Basal Area }\left(\mathrm{m}^{2}\right) \\
\text { Range }\end{array}$ & $0.008-0.129$ & $\begin{array}{c}0.008- \\
0.361\end{array}$ \\
\hline $\begin{array}{c}\text { Crown Projection } \\
\text { Area }\left(\mathrm{m}^{2}\right)\end{array}$ & $9.6-68.7$ & $4.2-119.7$ \\
\hline
\end{tabular}

\section{CONCLUSION}

Rainfall partitioning into Tf and Sf were estimated for both alluvial and heath forest in the Sepilok Forest Reserve, Sandakan. Tf was measured within the study period with an average of $76.8 \%$ of Pg over the alluvial forest plots and 89.5 $\%$ in the heath forest plots. Estimated Sf fraction in alluvial forest is $0.2 \%$ and $0.5 \%$ in heath forest as of the incident rainfall. However, we may underestimate the amount of Sf in the study area since only trees with Dbh $10 \mathrm{~cm}$ and above were measured for Sf generation (Manfroi et. al., 2004). The amount of Pg received in the study site was found to be the major contributor influencing the redistribution of rainfall under the forest canopy as of Tf estimation (high linear correlation). At some extend forest stand structure and tree physical characteristic i.e., Dbh, height and AGB, does play a role in the generation of $\mathrm{Tf}$ and $\mathrm{Sf}$.

\section{ACKNOWLEDGEMENTS}

This research was supported by the Malaysia Ministry of Higher Education and Universiti Malaysia Sabah under the Research Acculturation Collaborative Effort (RACE) Grant and Research Priority Areas Grant Scheme (SGPUMS), respectively. We would also like to thank the staffs of Sabah 
Forestry Department for their help and support to our research.

\section{REFERENCES}

Aisah, S. S., Yusop, Z., Noguchi, S. \& Rahman, K.A. 2012. Rainfall partitioning in a young Hopeaodorata plantation. Journal of Tropical Forest Science, 147-161.

Asdak, C., Jarvis, P. G., Van Gardingen, P. \& Prazer, A. 1998. Rainfall interception loss in unlogged and logged forest areas of Central Kalimantan, Indonesia. Journal of Hydrology, 206: 237-244.

Chappell, N.A., Bidin, K. \& Tych, W. 2001. Modelling rainfall and canopy controls on net-precipitation beneath selectively-logged tropical forest. Plant Ecology, 153, 215229.

Chave, J., Réjou-Méchain, M., Búrquez, A., Chidumayo, E., Colgan, M.S., Delitti, W.B.C., Duque, A., Eid, T., Fearnside, P.M., Goodman, R.C., Henry, M., Martínez-Yrízar, A., Mugasha, W.A., Muller-Landau, H.C., Mencuccini, M., Nelson, B.W., Ngomanda, A., Nogueira, E.M., OrtizMalavassi, E., Pélissier, R., Ploton, P., Ryan, C.M., Saldarriaga, J.G., \& Vieilledent, G. 2014. Improved allometric models to estimate the aboveground biomass of tropical trees. Glob. Change Biol, 20, 3177-3190.

Crockford, R.H. \& Richardson, D.P. 2000. Partitioning of rainfall into throughfall, stemflow and interception: Effect of forest type, ground cover and climate. Hydrological Processes, 14 (16-17), 2903-2920.

Dietz, J., Hölscher, D. \& Leuschner, C. 2006. Rainfall partitioning in relation to forest structure in differently managed montane forest stands in Central Sulawesi, Indonesia. Forest Ecology and Management, 237 (1), 170178 .

Germer, S., Elsenbeer, H. \& Moraes, J.M. 2006. Throughfall and temporal trends of rainfall redistribution in an open tropical rainforest, south-western Amazonia (Rondônia, Brazil). Hydrology and Earth System Sciences Discussions, 10 (3), 383-393.

Hofhansl, F., Wanek, W., Drage, S., Huber, W., Weissenhofer, A. \& Richter, A. 2012. Controls of hydrochemical fluxes via stemflow in tropical lowland rainforests: Effects of meteorology and vegetation characteristics. Journal of Hydrology, 452/253, 247-258. Holwerda, F., Scatena, F. N. \& Bruijnzeel, L. A. 2006. Throughfall in a Puerto Rican lower montane rain forest: A comparison of sampling strategies. Journal of Hydrology, $327,592-602$.

Hutton, W. 2013. Sepilok Forest. Sabah Forestry Department, Kota Kinabalu.

Jiménez-Rodríguez, C.D. \& Calvo-Alvarado, J. 2014. An Evaluation of Rainfall Interception In Sanchez-Azofeifa, A., Powers, J. S., Fernandes, G. W. \& Quesada, M (Eds.), Tropical Dry Forests in the Americas: Ecology, Conservation and Management, 249.CRC Press.

Kato, H., Onda, Y., Nanko, K., Gomi, T., Yamanaka, T. \& Kawaguchi, S. 2013. Effect of canopy interception on spatial variability and isotopic composition of throughfall in Japanese cypress plantations. Journal of Hydrology, $504,1-11$

Levia, D.F., Van Stan, J.T., Mage, S.M. \& Kelley-Hauske, P.W. 2010. Temporal variability of stemflow volume in a beech-yellow poplar forest in relation to tree species and size. Journal of Hydrology, 380 (1), 112-120.

Liu, G., Du, S., Peng, S. \& Wang, G. 2013. Rainfall interception in two contrasting forest types in the Mount Gongga area of Eastern Tibet, China. Hydrology: Current Research, 4, 161. doi: 10.4172/2157-7587.1000161.

Loescher, H. W., Powers, J. S. \& Oberbauer, S. F. 2002. Spatial variation of throughfall volume in an old-growth tropical wet forest, Costa Rica. Journal of Tropical Ecology, 18, 397-407.

Macinnis-Ng, C.M., Flores, E.E., Müller, H. \& Schwendenmann, L. 2012. Rainfall partitioning into throughfall and stemflow and associated nutrient fluxes: land use impacts in a lower montane tropical region of Panama. Biogeochemistry, 111 (1-3), 661-676

McJannet, D., Wallace, J. \& Reddell, P. 2007. Precipitation interception in Australian tropical rainforests: I. Measurement of stemflow, throughfall and cloud interception. Hydrological Processes, 21 (13), 1692-1702. 
Molina, A.J. \& del Campo, A.D. 2012. The effects of experimental thinning on throughfall and stemflow: a contribution towards hydrology-oriented silviculture in Aleppo pine plantations. Forest Ecology and Management, 269, 206-213.

Nilus, R. 2004. Effect of edaphic variation on forest structure, dynamics, diversity and regeneration in a lowland tropical rainforest in Borneo. School of Biological Sciences: University of Aberdeen, United Kingdom.

Park, A. \& Cameron, J. L. 2008. The influence of canopy traits on throughfall and stemflow in five tropical trees growing in a Panamanian Plantations. Forest Ecology and Management, 255, 1915-1925.

Staelens, J., De Schrijver, A., Verheyen, K. \& Verhoest, N.E. 2008. Rainfall partitioning into throughfall, stemflow, and interception within a single beech (Fagus sylvatica L.) canopy: influence of foliation, rain event characteristics, and meteorology. Hydrological Processes, 22 (1), 33-45.

Thimonier, A. 1998. Measurement of atmospheric deposition under forest canopies: some recommendations for equipment and sampling design. Environmental Monitoring and Assessment, 52 (3), 353-387.

Vernimmen, R. R. E., Bruijnzeel, L.A., Romdoni, A. \&
Proctor, J. 2007. Rainfall interception in three contrasting lowland rain forest types in Central Kalimantan, Indonesia. Journal of Hydrology, 340, 217-232.

Whitmore, T.C. 1975. Tropical rain forest of the Far East. Oxford University Press, London.

Woodget, A. S., Donoghue, D. N. M. \& Carbonneau, P. 2007. An assessment of airborne lidar for forest growth studies. Ekscentar, 10, 47-52.

Mui-How, P., Shazrul Azwan, J., Wong, O. C., Ioki, K., Maznah, M., Nilus, R., Coomes, D. A., Maycock, C. R. \& Hashim, M. 2017. Synergistic use of Landsat 8 OLI image and airborne LiDAR data for above-ground biomass estimation in tropical lowland rainforests. Forest Ecology and Management, 406, 163-171.

Yusop, Z., Yen, C.S. \& Hui, C.J. 2003. Throughfall, stemflow and interception loss of old rubber trees. Jurnal Kejuruteraan Awam, 15 (1), 24-33.

Zimmermann, A., Germer, S., Neill, C., Krusche, A.V. and Elsenbeer, H. 2008. Spatio-temporal patterns of throughfall and solute deposition in an open tropical rain forest. Journal of Hydrology, 360 (1), 87-102. 